\title{
Towards an Ecological Consciousness
}

\section{A. R. Agwan}

E. F. Schumacher, the author of Small Is Beautiful, said, "We are at war with Nature and if by chance we win the war, we shall be the loser." This paradox of modern humanity is not universally accepted. However, there is hardly any visible sign of a deceleration in humanity's unilateral war against the environment. Consequently, humanity is drawing closer and nearer to an imminent debacle.

Although "the voices of peace" for solving the crisis could be heard as early as the late 1940 s, their mediation has come to be regarded as valuable only recently. As a result, the global environmental movement has started shaping the course of developmental strategies. But, unfortunately, the growing concern over environmental devastation is still superficial and not viewed holistically. The ongoing concerns are limited to the extent of the exploitation of natural resources and the sustainability of the developmental processes. However, a few voices that consider the predicament from a holistic viewpoint and in a perspective of "deep ecology" are certainly audible in the global debate. The proponents of the holistic approach feel that humanity's present awareness of the environmental crisis is not sufficient. What is needed, according to them, is a dispassionate ecological consciousness emanating from the synthesis of the complete experience of humanity since the dawn of civilization and also taking into consideration all facets of the ultimate reality.

\section{The New Ecological Realism}

For quite some time, a relational perspective has been stressed in discussions about understanding and solving the ecological crisis. According to this viewpoint, "nature is a web of relations" and therefore "denial of relationality is denial of being" (Skolimowski 1991). Furthermore, it expands the frontiers of the relationality of the human community to the greater relationality of all biotic and abiotic members of the biosphere and beyond. A concept of "the cosmic family" has been envisaged by advocates of this vision, and humanity is expected to mold its behavior patterns so that human beings can fulfill their obligations towards the vast family and honor all relations while deriving benefits from the resource pool of their cultural and physical environments.

In its wake, a movement for deep ecology has been proposed. The term "deep ecology" signifies the encouragement of a more profound un-

A. R. Agwan is the director of the Institute of Objective Studies, New Delhi, India. 
derstanding of the ecological balance (Fernandes 1991). Indeed, deep ecology goes beyond the scientific framework and its technological means and ways to an intuitive awareness of the oneness of all life and the interdependence of its multiple manifestations. This also denotes what is called "an authentic human ecology" (John Paul II 1990).

The emerging perspective highlights the integrity of creation and the solidarity of "cosmic citizens" while at the same time espousing the need for discovering the intrinsic value of creation. Anthropocentrism has no place in this framework, and humanity emerges as an integral part of the whole. This view also urges human beings to accept the complementarity of humanity's role in the biosphere and to appreciate the intricate balance of natural phenomena that sustain its life on this planet.

This new ecological realism has its roots in the vast store of human experience down the ages and can be elaborated more lucidly in the religious worldview. Therefore, a multireligious understanding of the environmental crisis, in the context of human development, is relevant for a better illustration of the relational perspective of the human environment.

\section{The Integrity of Creation}

Most religious traditions depict nature as the manifestation of God, an ultimate theophany that both veils and reveals God. The relationship between God and nature is that of Creator and creation. Judaism and Christianity emphasize that "God has never left Himself without witnesses and the abiding witness in His creation as it relates to our life: the rains $\mathrm{He}$ sends in due seasons, the harvest that ripens the food we eat and the good cheer that fills our heart. These testify to His existence, presence, and love" (Fernandes 1991). In Islamic phraseology, the whole universe is a book in which the phenomena of nature are written in the form of signs (āyāt) and the Biblical vestiga Dei (Nasr 1990). On the one hand, all the creatures obey His commands and fulfill their ordained obligations. On the other, they continuously urge humanity to realize its own place and role in nature. In the teachings of Zoroaster, Ahura Mazda (Lord of Life and Wisdom), bound the entire world by a divine law (asha). This same concept found in the Vedic (rta), Confucian (the Way of Heaven), and Qur'anic (fasawwā) traditions, for they all point to the cosmic order and the law followed by "cosmic citizens." In these traditions, it is believed that all living and nonliving things in nature reflect the glory and love of God. Thus, nature attains a sort of sacramental character whereby each of its inhabitants should be respected and taken care of by others.

The Qur'an says that everything is created in due proportion and with an intricate balance (mizān). Humanity is told to discover this balance, 
which encompasses the animate and inanimate worlds, and within each individual's own self and then to submit to the law and order of the universe as its other inhabitants have done. As nature provided both material and spiritual sustenance for humanity, humanity should appreciate the forces of nature that make its life possible in the planetary ecosystem.

In Christianity, "the Gospels depict Jesus as taking delight in contemplating Nature and in inviting us to look long and close at the flowers in the field and the birds in the sky, and to sense in them the presence, work and loving concern of the Father who makes sure that birds are fed and flowers are clothed more splendidly than any queen or king" (Fernandes 1991). The flowers and the birds, as well as the other inhabitants of the biosphere, are thus a "revelation of God's justice which consists in ample provision for every creature of whatever is necessary for it to be itself, to grow to fullness and completion" (ibid.).

Jain belief is embedded in the belief of physical (jiva) and psychic (ajiva) orders belonging to the world, orders in which all natural phenomena are the interplay of both orders. Here the elements of panchakaya (i.e., water, air, fire, flora, and fauna) are made very useful by the interplay of the two cosmic orders. "In the Zoroastrian and Hindu traditions, an all-pervading guardian spirit, fravashi and paramatma respectively, unify life. The cosmic order ( $r t a)$ in the Vedas, as opposed to chaos (anrta), is in some sense the work of Varuna. His law and his order were to be obeyed by all that was in nature and had to be similarly obeyed by humanity. In Guru Granth, the Sikh holy book, "the marvelous multiplicity of creation" has been praised (Singh 1992).

In the Hindu, Jain, and Buddhist religions, humans acquire consciousness due to their respective spirits and, similarly, all other objects of nature derive action from their own spirits. Here, humanity's relation with nature takes a reverential shape that, if carried to extremes, can result in nature worship, such as is sometimes seen among the Hindus.

The system of relationships outlined in Confucianism has at its heart the concept of reciprocity $(s h u)$, wherein humanity is expected to reciprocate the favors vested in its life from relations and nature. Japanese Shintoism has, in all of its aspects, an extremely close relation with the natural world. Shinto shrines are usually built in sacred groves that express something of the mystery and peace pervading the beautiful countryside.

In the Jewish, Christian, and Islamic traditions, although humanity is placed intrinsically in the web of nature, its position is slightly different. With free will and gifted faculties, a human being has an edge over other creatures in the sense that he/she can follow or violate the intrinsic law of nature. However, a human being's inherent characteristics are designed to reconcile with nature and its inhabitants. According to the Bible's 
Book of Genesis, a human being is a reflection of God (reflecto Dei). Therefore, he/she is both a participant in the creative work of God and a coevolver and cocreator in the blessed world of all living beings. Similarly, the Qur'an says that humans are created in the nature of God (fitrat Alläh), which demands that they practice justice, love, and benevolence.

In Islam, humanity is the wise inheritor (khalifah) of the planetary ecosystem as well as the one for whom all things in the earth and in the heavens are made complaisant (musakhkhar) so that human life may fully benefit from the bounties of nature. In Judaism and Christianity, the vast kingdom of God is entrusted to humanity in its role as a caretaker with limited delegated powers. Therefore humanity's superiority over other inhabitants does not place it above the laws that are operative in nature, but rather in a condition of equilibrium with all other inhabitants.

It is obvious from the above discussion that humanity's religious experience impresses upon it the integrity of creation and the harmony and balance of nature. In addition, it emphasizes that each human being should appreciate and glorify the fineness and perfection of that order and balance intrinsic in one's own nature and that one should pattern his/her behavior in congruence with the environment while discovering and harnessing the benevolence of nature.

\section{Man-Made Environmental Imbalances}

The long history of humanity proves that human behavior oscillates between one extreme or the other when it comes to nature, for history records very few instances of balanced human behavior towards nature. Humanity's misuse or disuse of its faculties has turned human beings into zombies, while a reverential attitude towards nature has made others its worshippers and subjects, an enslavement that has been quite common throughout human history. However, when the fruits of transgression dawned upon humanity, it began to enslave nature. The dominance of such contemporary philosophies as secularism, materialism, and scientism has prodded contemporary humanity to bring into being a cultural environment wherein it attempts not only to control human beings but also to conquer nature, as if it were an enemy.

The discoveries of nature and the deep meaning of its beauty and balance have failed to stimulate in a conquest-minded humanity any appreciation of nature. Rather, the unfolding of nature's properties has led humanity to exploit natural resources, to develop and then implement unsound strategies, to practice scientific arrogance, and to form a wasteful culture. To modern humanity, human beings represent a global market of vast numbers of human consumers of the gold mine called nature. The re- 
sulting marketing spree has motivated powerful nations to compete for control of consumers and to exploit nature's resources. So far, the outcome has been war, enslavement, and chaos.

By the close of the twentieth century, many large-scale human activities (i.e., industrialization, agriculture, urbanization, and transportation) had shown a tendency to alter the natural balance of biotic and abiotic components in a rather stable ecosystem. Alterations in the hydrogeochemical cycle, interventions in input-output balances in an ecosystem's energy flow, the accumulation of toxic substances, overproduction or depletion of certain essential substances, eutrophication and deforestation, and other results of the unfettered exploitation of nature have greatly threatened several equilibria in the biosphere. The accumulation of wealth and power in a few hands, the advent of neocolonialism, the forceful attainment of a unipolar world, the political use of natural resources, and guided developmental strategies, to name just a few, have enslaved, fragmented, stripped of dignity, and consigned humanity to indefinite poverty.

In the Buddhist tradition, humanity is taught to follow a balanced view of life (madhyam marg). Since the phenomenon of desire is intrinsic to human nature, human beings should learn that the reason for all miseries (dhukh) is insatiable desire (trishna). In Hinduism, such externalized human behavior is seen as sensuality $(\mathrm{kam})$, vengeance ( $\mathrm{krodh})$, arrogance $(\mathrm{mad})$, and greed $(l o b h)$. Human selfishness is responsible for unbalanced behavior, a factor personified in the Buddhist worldview as Mara, in the Semitic religions as Satan, and in Zoroastrianism as the Evil Spirit, for all of them cause disorder on earth. Such disorder, the Vedic anrta or the Qur'anic fasād, is seen as being the result of several actions by humanity: a) a direct outcome of the overuse, misuse, or disuse of human and natural resources due to deformity in the five realms of the biosphere, called the panchakaya in Jainism; b) humanity's failure as a coevolver and cocreator according to the Bible; or c) the transgression of ordained limits for human behavior, depicted in the Qur'an as tatghaw. The selfish motive of human behavior prevents human beings from seeing the world in a relational perspective wherein humans is obliged to practice reciprocity, a central tenet of Confucianism. According to Christianity, "greed has alienated man from God, from the entire Creation and from himself and his fellowmen" (Pandit 1992). As a result human beings, impelled by greed, have attempted to "kill the goose that lays the golden eggs" in order to get all of those golden eggs for themselves. The result of such behavior is a situation that threatens humanity's very survival.

Strangely enough, nature is not watching the rape of its resources silently. It has meted out a severe punishment: wars, tensions, poverty, calamities, acid rain, showers of ultraviolet rays through the ruptured 
ozone layer, desertification, earthquakes, AIDS, pollution, the greenhouse effect, suicidal accumulations of toxic substances in the human body, Chernobyl and similar disasters, the extinction of animal and plant species, floods, droughts, and other natural disasters. Nature continues to remind humanity that it is not a machine in the hand of humans, as we have been assured by Cartesian and Baconian scientism. It is rather a sensitive whole with both creative and corrective capabilities. Humanity has now reached the point at which it must change its attitude towards nature, or else nature will continue to thrust ever-harsher catastrophes upon it.

\section{The Role of Eco-Ethics}

Religious traditions are replete with general guidelines for solving the various human crises that confront humanity periodically as well as at present. A religious paradigm for the management of the current environmental crisis can be developed by bringing together various sound principles derived from major world religions and then applying that paradigm to developmental strategies.

The concept of common good, as expressed in modern concepts of welfare, is central to the religious experience of humanity. Pope John XXIII defines the common good as "the sum total of those conditions of social living whereby men are enabled more fully and more readily to achieve their perfection" (John XXIII 1961). The concept is illustrated in a Hindu Sanskrit prayer that begins with the words sarve bhavanti sukhinah, which is a verbalization of the wish that all beings achieve happiness, enjoy health, and become good. Buddhists say that individuals need to apply the third eye, the Eye of Wisdom which is both pure and heavenly, in order to see clearly and deeply into the conditions of living beings. Such an effort may virtually lead individuals to change their attitudes towards others so that the "happiness of all that live" can be attained. As Mahavira, the founder of Jainism, taught, reality is multifaceted (anekant). Thus a holistic view of life is to be contemplated for achieving "liberation" from the cycle of rebirth and, therefore, nonviolence (ahimsa) should be practiced by all human beings.

When nonviolence is understood in its deep meaning, it is close to the suggestion of Commoner: in order to resolve the crisis "we shall have to deny ourselves the luxury of tolerating poverty, racial discrimination and war. There are only two options before us, either the rational social organisation of the use and distribution of the Earth's resources or a new barbarism" (Commoner 1972). Ending desire, as taught by Buddha, has great relevance in this context, but it can only be realized if one adopts right (as defined by Buddha) views, aspirations, communication, behavior, 
earnings, efforts, thoughts, and contemplation. This approach to life may also be derived by following the Way of Heaven, Dĩn, or Dharma.

John Hinnells has called Zoroastrianism the world's first ecological religion, for Zoroaster taught that "the most important task of man is to preserve unity not only in Nature but in all beings" (Sethna 1992). Zoroastrian prayers are full of praise of mountains, streams of water, oceans, the green springs of corn, flying birds, and "Mother Earth and all her good creations." The Parsees, contemporary followers of Zoroaster, are told that "every single flower is appropriate to an angel." In their Jashan ceremony, they revere and remember fire, water, the animal and the vegetable kingdoms, the earth, the minerals and metals in the earth and the air, and even the ether that occupies space.

Such elements are found in other religions. Hindus, Jews, Christians, Buddhists, and Sikhs are taught to sing the glory of nature, and various ceremonies are traditionally performed to bring the followers close to nature. The Jewish festival Tu-Bishewat is celebrated as the new year of trees. Shabuoth is a festival during which the first fruits of the fields and trees are offered as a thanksgiving to God, while the Sukkoth celebration includes a week-long meditation under a special booth made of branches. The same sort of ecological wisdom is seen in the Christian celebrations of Christmas and Easter, and humanity is reminded in the Book of Genesis that God has put it in charge of fish, birds and all wild animals. Such a relationship is even more pronounced in the case of St. Francis, who sang of "Brother Sun" and "Sister Moon." The Christian concern with suffering may extend to suffering at all levels of the biosphere.

Similarly, Buddhist literature is full of detailed instructions for preserving and nurturing the human habitat. In the Vinaya Sutra, the planting of trees is said to be within the obligations of a bhikku (monk). One tree in particular, the fig tree, features prominently in Buddhist wisdom. The Buddhist prayer known as the "Prayer for the Happiness of All That Lives" has acquired a central place in the offerings of several Buddhist sects. Hindu prayers and ceremonies are embedded in the love for nature to such an extent that some adherents worship practically all objects in nature. The Baisakhi festival of the Sikhs is celebrated in the midst of nature to show human gratitude, as Guru Nanak taught the Sikhs that "God sleeps in the tree, dreams in the animal, and wakes in man" (Singh 1992).

Islam does not enjoin a follower to sing the glory of nature. Rather, a Muslim is taught to join all of creation in the glory of God, to realize that each inhabitant in the biosphere has its own community, and that all are in fellowship with one another. In the Qur'an, the community of ants (ummat al naml) has been appreciated, for, according to a narration from the Prophet, God would not allow a prophet to destroy a nest of ants after 
one of its members had bitten him. Muslims are taught to eat the fruits of trees without breaking their branches, to avoid polluting standing water with impure things, and are encouraged to grow a plant even if the Day of Judgment were to come tomorrow (Agwan 1992). Humanity, in spite of its faculties, is in a relation of balance with all other members of creation. The Qur'an stresses the water cycle, the atmosphere, vegetation, oceans, and mountains in the life and well-being of humanity. As a result, a Muslim is enjoined to adopt an appreciative approach towards nature.

The above discussion makes it evident that eco-ethics have been a part of religious teachings from time immemorial and that they have great relevance to contemporary developmental strategies in the context of the prevailing environmental crisis.

\section{Development in the Relational Perspective}

In the foregoing, an altogether different view emerges for human development. This may be projected through the following propositions:

1. Developmental plans and strategies should be embedded in the preservation and promotion of the integrity of creation. This is possible through the inculcation of transcendental reasoning, the appreciation of beauty and balance in nature, the just distribution of natural resources, and the humanization of thought processes.

2. The spirit of inquiry as regards science and technology, which are the tools of development, should explain natural processes and explore the interrelatedness of natural phenomena and their deep meaning.

3. The tunnel-vision approach for material progress should be replaced by a holistic viewpoint wherein happiness and the common good of all living beings is enshrined as the prime objective of human intervention in the natural world. Transient goals should not overshadow a wholesome future at each and every level of development.

4. The principle of reciprocity should be included in all developmental practices so that unipolar interests can be minimized. In addition, an obligation for recompense or restitution could be stressed while harnessing human and natural resources.

5. The developmental processes should be envisioned as involving the decentralization of authority and the appreciation of the native fabric of the human environment. Furthermore, the process of globalization pertaining to development should take on a positive framework. 
6. Prevailing geopolitical tensions disrupt the world's harmony and amity and also divert available funds to such nondevelopmental sectors as the military, propaganda, and lobbying. Sustained efforts are needed to achieve universal peace, concord, and union. Linking resources to avoidable sectors of human development indirectly quickens environmental exploitation and must be checked vigilantly.

7. A set of universally honored eco-ethics and self-disciplining norms should be devised for policymakers, consultants, funding agencies, and developers committed to human progress. Programs for attitude development and ecological awareness that can get people to share in environmental management should be developed and implemented.

8. It should be realized that there is an upper limit to possible developmental attainments as regards maintaining the biospheric balance. Thus the question of desirability has a definite edge over the sustainability of planned development. Developers have a collective obligation to maintain and promote the stability of an intervened ecosystem. All efforts directed towards harnessing humanity's cultural and physical environments should abide by the limits of the zero-state-trending intrinsic in a given ecosystem.

\section{The UNCED and Beyond}

The United Nations Conference on Environment and Development (UNCED), held in Rio de Janeiro, Brazil, during 13-14 June 1992, was the latest and so far the largest assembly of world leaders convened for the specific purpose of discussing environmental issues. This conference, also called the Earth Summit, brought to light once again the differing perceptions of developed and developing nations on the genesis, state, and management of the ecological crisis. No significant achievement was recorded, the only exception being that it focused international attention on the environment. The conference generally remained another political forum for promoting the economic interests of the attending countries.

Viewing the summit from a normative and an ideological perspective, it seems that the world is still not attentive to the real cause of the imminent environmental holocaust. However "Agenda 21," which was adopted by the conference, discusses at certain places the significance of religious intervention in resolving the global environmental crisis. It shows that the pressure exerted by the religious world, which was channeled through such organizations as the World Conference on Religion and Peace, did have some positive results. Ethical values and traditional knowledge have 
been appreciated in Agenda 21 and at other places (see especially part 3, pages 35 and 38 and part 4, pages 14, 19, and 24 (United Nations 1992]).

It has been stressed that adopting ethical principles and codes of practice for the scientific and technological community would both enhance professionalism and help in "recognizing the continuing evolution and uncertainty of scientific knowledge." Agenda 21 visualizes "strengthening and establishing national advisory groups on environmental and developmental ethics" and "extending education and training in developmental and environmental ethical issues to integrate such objectives into education curricula and research priorities." It also states that education is "critical for achieving environmental and ethical awareness, values, attitudes, skills and behaviour consistent with sustainable development."

Apart from recognizing the importance of environmental ethics, the UNCED has accepted the role of "traditional knowledge." Agenda 21 points out the need "to develop methods to link findings of the established sciences with the indigenous knowledge of different cultures. They should be developed at the local level and should concentrate on the links between the traditional knowledge of indigenous groups and corresponding current advance science." At another place, the document emphasized development of "alternative strategies including indigenous approaches."

Obviously, the world community is going to consider some alternative models emanating from an ethical vision. Such models would have a place for those intrafaith and interfaith efforts intended to resolve the crisis. Through these entry points, the religious community of the world, especially the ummah of tawhid, the Islamic doctrine of the unity of life, should reflect its wisdom in providing sound life-systems promoting sustainable human endeavors in the midst of the present predicament.

\section{References}

Agwan, A. R. "The Environmental Concern of Islam." New Delhi: Institute of Objective Studies, 1992.

Commoner, Barry. The Closing Circle. London: Jonathan Cape, 1972. Fernandes, Archbishop Angelo. "The Ecological Crisis and the Search for Peace." New Delhi: World Conference on Religion and Peace, 1991. John XXIII. Master et Magistra (Christianity and Social Progress: Encyclical Letter of Pope John XXIII, 15 May 1961), edited by Donald R. Campion and Eugene K. Culhane. New York: The America Press, 1961 , no. 65.

John Paul II. "Centesimus Annus (Commemorating the Century of Rerum Novarum and Addressing Social Questions in Contemporary Perspective: Encyclical Letter of Pope John Paul II, 1 May 1991)." The Pope 
Speaks: The Church Documents Bimonthly 36, no. 5 (SeptemberOctober 1991).

Nasr, Seyyed H. "Islam and the Environmental Crisis." MAAS Journal of Islamic Science 6, no. 2 (July-December 1990).

Pandit, Motilal. "A Christian Understanding of Nature." In Religion, $\mathrm{Na}$ ture and Survival. New Delhi: Inter-Religious Forum for Communal Harmony, 1992.

Sethna, A. M. "Zoroastrianism and the Protection of Nature." In Religion, Nature and Survival. New Delhi: Inter-Religious Forum for Communal Harmony, 1992.

Singh, Mohinder. "Conservation of Nature: The Sikh Perspective." In Religion, Nature and Survival. New Delhi: Inter-Religious Forum for Communal Harmony, 1992.

Skolimowski, Henryk. Dancing of Shiva in the Ecological Age. New Delhi: Clarion Press, 1991.

United Nations Conference on Environment and Development, 1990. Document no. Conf.A/51, English, part 3 and 4. 